\title{
Public Service Motivation Differences Between Permanent and Contract Employees in The Local Government
}

\author{
WAYU EKO YUDIATMAJA

\begin{abstract}
Department of Public Administration, Faculty of Social and Political Sciences, email: wayuguci@umrah.ac.id
\end{abstract} \\ Universitas Maritim Raja Ali Haji, Jl. Raya Dompak, Tanjungpinang, Kepulauan Riau
}

\begin{abstract}
This article examines the difference of public service motivation (PSM) at street-level bureaucracy in Indonesia. Focus of this study is to review the difference of public service motivation between permanent and contract employees in sub-districts of Tanjungpinang, Kepulauan Riau. The dimensions and indicators of Perry's (1996) measurement of PSM are used to analyze that difference. Independent sample t-test has employed to 129 government employees and 74 non-government employees in Tanjungpinang. Unlike those in developed countries which showed that PSM of its civil services is higher than PSM of contract employees, the findings of this research prove there are no differences between PSM of permanent and contract employees in Indonesia. It rejects the conclusion of foreign scholars suggesting the PSM construct was viable for international environment.
\end{abstract}

Keywords: public service motivation, permanent and contract employees

\section{Introduction}

This paper discusses the difference of public service motivation (PSM) among civil services in Indonesia. Focus of this paper is to examine the distinction of permanent and contract employees working at the streetlevel bureaucracy in the local government. Generally, PSM can be called the motives of public servant to work with the spirit of serving for the nation and the people. This motives differ between public and private employees (Perry and Wise, 1990; Gabris and Simo, 1995; Houston, 2000). Frederickson and Hart (1985) showed that employees in the public sector have a spirit to serve for the public and patriotism for the nation. This spirit is a part of intrinsic motivation and altruistically owned by the apparatus of public sector. In its development, the altruistic value which forming the basis of attitude and behavior of bureaucrats is called PSM (Perry, 1997; 2000; Vandenabeele, 2007).

PSM has become prominent topic in the study of public administration. At least, since a last few decades, the readability of researchers in this field is rising (Perry and Hondeghem, 2008a; 2008b; Perry et al., 2010; Perry, 2014). The development of PSM was originally inseparable from the work undertaken by some scholars (Perry and Wise, 1990; Crewson,1997). Rainey studies $(1979 ; 1982 ; 1983 ; 2003)$ found that employees in the public sector reflected a negative perception for the material reward and gave a positive attention for the spirit to serve and other altruistic behaviors. This study was supported by the findings of Wittmer (1991) which show that managers in the public sector have differences with those in private sector and hybrid organizations in responding the value and compensation. The result of Wittmer's (1991) research revealed that the economic rewards are main motivator for managers in the business sector, while managers in the public sector and hybrid organizations response relatively lower to the economic incentives.

At the international level, the study conducted by experts shows that PSM viable for cross-environment or country. Crewson's study (1995) on federal government and private employees in United States between 1980 and 1990 suggested that government employees have better motivation and performance than employees in the private

Received: May 16, 2017, Revision: September 11, 2017, Accepted: December 20, 2017

Print ISSN: 0215-8175; Online ISSN: 2303-2499. DOI: http://dx.doi.org/10.29313/mimbar.v33i2.2516.329-340

Accredited B based on the decree No.040/P/2014, valid on February, 18, 2014 until February, 18, 2019. Indexed by DOAJ, Sinta, IPI 
sector. Brewer, Selden and Facer II (2000) also revealed that employees in the public sector have norms and strong emotions to serve as government officials. Motivation and dedication are considered to attract certain individuals to serve in the public sector and help realize a consistent work behavior for public interest. It was supported by the findings of Bertelli (2006) on the federal government employees in the United States. According to Bertelli (2006), intrinsic motivation was more encouraging for federal employees to choose a career as public servant and provided maximum performance as public official. In Europe, the study employed by Vandenabeele et al. (2004), Vandenabeele et al. (2006), Leisink and Steijn (2009), Ritz (2009), Vandenabeele et al. (2010) were consistent with the findings in the United States. Studies conducted by several scholars in South Korea also confirmed the study of American and European scholars (Choi, 2001; Kim, 2006; Kim, 2009). In Australia, the study of Taylor $(2007 ; 2008)$ also proved the same conclusions. In addition, the study conducted by Liu et al. (2008), Liu (2009), Liu et al. (2014) showed similar findings. In general, a trend that occurred in European, South Korea, Australia, and China showed that employees in the public sector have highly motivated to help public service delivered.

Empirically, nowadays, Indonesia has become the country with the largest number of public employees in the world. In 2005, the number of civil service in Indonesia has reached 3.74 million people or equivalent to $1.7 \%$ of the total population. Meanwhile, compared to the New Order era (19661998), the number of civil service was decreased. In the New Order, the ratio of civil service was $2.1 \%$ of the total population (Tjiptoherijanto, 2007: 32). In general, it is a global phenomenon because some countries had also decrease the number of public employee, for instance India (1.2\%), Pakistan $(1.5 \%)$, Filipina $(2.1 \%)$, and Vietnam (3.2\%) (Heller and Tait, 1983; Schiavo-Campo, 1998; World Bank, 2003). Data from the Central Bureau of Statistics (2015) noted that in 2014 , the number of civil service in Indonesia has reached 4.4 million people or 1.8 from the total population of Indonesia. However, in 1985 there were 1.7 million employees in the local government or $55 \%$ of total employees working for local governments (province or regency or city) (King, 1988: 252). Subsequently, in 2014, there were 3.5 million employees in the local governments of
Indonesia, equivalent to $80 \%$ of the total civil service (Central Bureau of Statistics, 2015).

Post-New Order, Indonesia began to adopt the principle of merit system in public sector personnel management. In the process of recruiting candidates for civil servants (Calon Pegawai Negeri Sipil, CPNS), since 2006 the central government began to implement the open test for any applicant who wants to be a civil servant to all government agencies in Indonesia, both central and local governments (Prasojo et al, 2007). However, to appreciate the devotion of temporary employees who had been long-serving, government provides the opportunity as permanent employees for the contract employees through the scheme of Category 1 (K1) and Category 2 (K2). It is stipulated in Government Regulation No. 48 of 2005 about Appointment of Contract Employees as a Permanent Employees. The issue raised at this time is related to the performance and motivation of contract and permanent employees. Some studies showed that the performance and motivation of contract employees is lower than permanent employees (Nugroho, 2004) and lack of accountability (Baharuddin, 2015) and service quality (Hardiyansyah, 2012; Yudiatmaja et al, 2017). Yet, there were other studies which prove that contract employee's performance was higher than permanent employee's (Ahmad dan Baharuddin, 2011; Octarina, 2013).

This research is important to understand human resources management in Indonesian public sector which has contextual differences with other developed countries. Outside the study conducted in the United States, Europe, South Korea, and China, PSM should be tested in the diverse socio-cultural context to gain an overview of PSM from a different perspective (Vandenabeele et al. 2006; Kim and Vandenabeele, 2010; Kim and Kim, 2016). The study of PSM in Indonesian context is still very limited. However, based on the results of the literature search, there are three studies examining PSM in Indonesia. Firstly, a study conducted by Komalasari et al. (2009) on the effect of PSM and organizational citizenship behavior (OCB) to performance of government organization in East Jawa Province. The findings in Bangkalan Regency, Pacitan Regency, Probolinggo Regency, and Kediri Regency showed that in government organizations, the level of OCB was lower than PSM. Further results from this study indicated job satisfaction and PSM have positive effect 
on organizational performance, while the OCB has not had a significant effect on organizational performance. Secondly, Yanti (2012) tested PSM and job satisfaction of permanent and contract employees working in health sector and local governments in Jambi. The results of this study revealed that PSM of permanent employees have higher motivation than contract employees. It is concluded that PSM affect employee's satisfaction. Third, Syamsir (2014) examined the relationship between PSM and sociodemographic variables. By referring to the case in Padang, Syamsir (2014) traced that PSM of civil services in Padang has lower motivation than PSM of civil services in the United States and Australia. It contributed to the study of PSM to focus on analyzing the socio-demographic factors, such as age, sex, marital status, educational level, income, and ideology influencing PSM. This study stated that PSM has correlation with sex, status, and income. Meanwhile, age, education, and ideology are only partially appertained to PSM.

The study of PSM can be categorized into six themes, which are construct and measurement, impact, antecedent, outcomes, organizational system, and its relationship with the type of other motivations (Perry and Hondeghem, 2008a; Kim and Vandenabeele, 2010). This study examined PSM in the construct and measurement themes. It also attempted to fill the gaps in our knowledge about PSM in two facets. At least, there are two novelties expected from this research; first, it sought to examine differences of PSM in two categories of public sector employees, permanent and contract employees, which has not been widely analyzed by the scholars; second, this research focused on PSM at the lower level employees which also has not received broadly attention from the researchers.

Based on the above description, the purposes of this study are to compare and test PSM differences between permanent and contract employees working on subdistricts [kelurahan] in Tanjungpinang, Kepulauan Riau. Question to be answered from this study is how the comparison of permanent and contract employees' PSM. Furthermore, this study also examines whether there is differences between PSM of permanent and contract employees. To answer these questions, this paper is divided into several sessions. Before discussing the differences between PSM of permanent and contract employees, it presents a review of the literature regarding PSM and street-level bureaucracy. Discussion about the distinctions and differences of PSM between permanent and contract employees will be presented after the section of the literature review.

PSM theory is constructed from motivational theories. Motivation is a general theory (Behn, 1995), while PSM is a more specific theory derived from the theories of motivation (Perry and Hondeghem, 2008a). The scholars have revealed since long time ago that intrinsic and extrinsic factors become substantial variables affecting employee motivation (Maslow, 1954; Adams, 1965; Deci, 1976; Bandura, 1977; Latham and Locke, 1979; Sansone and Harackiewicz, 2000; Frey and Osterloh, 2002; Latham, 2007; Kanfer et al, 2008; Thomas, 2009). Intrinsic variables is a variable of driving force comes from within an employee, such as dedication, desire to be useful to others, and interest in public issues. Meanwhile, extrinsic variables refer to the variables which come from outside employees, generally the economic factors, for instance incentive, compensation, salary, and various other rewards.

Conceptually, there is no accepted definition of PSM in general. According to Perry and Wise (1990), PSM is the tendency of an individual to respond to motive founded uniquely and usually revealed in the public institutions. Some scholars use the definition put forward by Perry and Wise (1990), while others define it in a different perspective. Crewson (1997) for example, wrote that PSM is individual motivation for servingnot included economic orientation-in order to benefit for the society, orientation for helping others, and spirit to obtain intrinsic achievement. According to Brewer and Selden (1998), PSM is the motivational force inducing a person to provide a useful service to others. Rainey and Steinbauer (1999) defined PSM as an altruistic motivation to serve people interest, nation, and humanity. Meanwhile, Vandenabeele et al. (2006) revealed that PSM is beliefs, values, and attitudes which does not put their own interests or group interests, promote wider public interests through its interaction with the public. Kjeldsen (2012) stated that PSM refers to broadly pro-social motivation which encourages a person to take action to help others and communities.

Perry (1990) may be cited as the drafter of PSM theory because Perry is not only the 
first person to define PSM, but also the first person to translate PSM theory into the scale and specific measurements. Using 40 item statements, Perry (1996) formulated PSM into six dimensions including; (1) attraction to policy making, (2) commitment to the public interest, (3) civic duty, (4) social justice, (5) compassion, (6) self-sacrifice. The formulation of PSM dimensions was obtained by Perry (1996) after reviewing the Frederickson and Hart's (1985) article, concluding that the primary motivation of public employees is the patriotism of benevolence. With the exception of self-sacrifice, these motivations related to the three categories of motivation as identified by Perry and Wise (1990), such as rational, norm-based, and affective. After employing the test to confirmatory factor analysis and reliability testing, Perry (1997) simplified PSM statement into 24 items and dimensions of PSM into four sub-scales, namely; (1) attraction to policy making, (2) commitment to the public interest, (3) compassion, and (4) self-sacrifice.

Besides Perry (1990; 1997), some scholars also expand the dimensions of PSM. Brewer et al. (2000) classified PSM into four conceptions of samaritan, communitarian, patriot, and humanitarian. Samaritan is a willingness to serve the public interest. Communitarian refers to behavior driven by a desire to carry out tasks and public services. Patriot is an attitude and behavior to protect, advocate, and willingness to act for public goodness. Humanitarian is an attempt to achieve social justice in society. Meanwhile, DeHart-Davis et al. (2006) categorized PSM into three dimensions, namely compassion, attraction to policymaking, and commitment to public service

In the west, some studies revealed that public sector employees have higher PSM than employees in the private sector. By analyzing the data from the General Social Survey (GSS) 1994, Federal Employee Attitude Survey (FEAS) in 1979, and the Institute of Electronic and Electrical Engineers (IEEE) 1994, Crewson (1997) indicated that intrinsic motivation of employees in the public sector was higher than those in private sector, while extrinsic motivation of employees in public sector was lower than employees in the private sector. Furthermore, Houston (2000) tested PSM using multivariate analysis. Refers to the data from the General Social Survey (GSS) 1994, Houston (2000) revealed 57.4\% employees in public sector to pay great attention with useful work (one of dimension of PSM) for many peoples. Then, the findings of Frank and Lewis (2004) confirm previous studies. The study conducted by Frank and Lewis (2004) tried to analyze intrinsic and extrinsic motivations affecting the work effort of public and private sector employees in the United States. From the data analysis, Frank and Lewis (2004) concluded that public sector employees have a higher intrinsic motivation than private sector employees. In addition, Frank and Lewis (2004) also suggested that public sector employees have a greater interest to realize the work effort and passion for helping others.

Buelens and Van den Broeck (2007) examined work motivation differences between public and private sector employees in Belgium. The survey was conducted on 3,314 private employees and 409 government employees. The study found that public sector employees are not affected by extrinsic motivation. Their study concluded that differences in the level of hierarchy have more influence on work motivation than sectoral differences. This study was supported by the findings of Lee and Wilkins (2011) toward the manager of public and private sectors. Lee and Wilkins (2011) tested seven variables of motivation and its relationship with the career choice between public and private managers. The variables are; (1) an opportunity to career development, (2) salary, (3) retirement plan, (4) sense of responsibility, (5) opportunity to share time and togetherness with family, (6) ability to serve the public interest, (7) volunteerism. Lee and Wilkins (2011) revealed variable of career development opportunity, pension plans, and ability to serve the public interest were larger owned by public sector managers. Variable opportunity to share time and togetherness with family and a sense of responsibility more owned by private sector employees. Meanwhile, variable of voluntary participation is more significant for the nonprofit sector employees.

Various studies on PSM also showed that PSM has implications for a wide range of dimensions in personnel management. Naff and Crum (1999) found that there was a significant relationship between PSM and job satisfaction, performance, intention to persist, and support for the changes. This findings were supported by several studies which found that there was a close relationship between PSM and performance of public sector organizations (Brewer and Selden 2000; Alonso and Lewis, 2001; Kim, 2005). Correspondingly, Ritz and Waldner 
(2011) showed that employees with high PSM will be motivated to improve his career in the public sector. Employees are not only motivated by compensation and desire to get higher positions in the public sector, but they are also driven by several factors, such as motivation from within to get more different and challenge of work, increasing career opportunities, and devotion to the public. Judging from the intention to resign, Morrison's study (2012) toward federal employees in the United States suggested that PSM affected employees' turn-over in the public sector. This study is consistent with Shim et al (2015) indicating that at the level of street-level bureaucracy, PSM can affect retention of public sector employees.

In recent years, using the scale and dimensions of Perry's PSM (1996), many researchers have tested the antecedent and effect factors of PSM (Perry, 1997, 2000; Choi, 2004; Camilleri, 2006; Castaing, 2006; Camilleri, 2007; Moynihan and Pandey, 2007; Perry et al, 2008; Christensen and Wright, 2011; Vandenabeele, 2011; Kachornkittiya et $\mathrm{al}, 2012$ ). From the test results, some studies claimed that PSM was viable for any condition and environment (Crewson, 1995; Brewer et al., 2000; Vandenabeele et al., 2004; Bertelli, 2006; Leisink and Steijn, 2009; Vandenabeele, et al., 2010). It means, when tested in a variety of social, economic, political, and different dimensions, PSM can be revealed. In addition, when compared by sector, it will be found that PSM of public sector employees is higher than PSM of private sector. Meanwhile, other studies indicated that the PSM was not fully in accordance with the socio-political, economic, and different cultures (Grindle, 1997; Benz, 2005; Buelens and Van den Broeck, 2007; Ritz and Brewer, 2013; Syamsir, 2014; Van de Walle et al, 2015). In other words, the dimensions of PSM are not always found in every condition and situation of different environment. There was no significant differences between PSM of public sector employees and PSM of private sector employees in some situations.

Based on the description in the background above, the hypotheses to be tested in this study consist of two parts, namely:

H1 PSM of permanent employees is higher than contract employees

H2 There is no significant differences between PSM of permanent and contract employees in the street-level bureaucracy

\section{Research Methods}

This research was conducted by survey approach. Questionnaire was used as a tool for collecting the data. The population in this study was all permanent and contract employees working in 18 sub-districts in Tanjungpinang. The sample size was chosen using the Slovin's formula (Tejada and Punzalan, 2012) with a tolerance limit of $5 \%$. The population of this study was 282 participants. The samples were taken by simple random

sampling method. These samples included 203 peoples, consisting of 129 permanent employees and 74 contract employees.

The questionnaire was drawn up which refers to the dimensions of PSM proposed by Perry (1996), which includes; attraction to policy making ( 3 items), commitment to the public interests and public duties (14 items), compassion ( 8 items), self-sacrifice ( 8 items). The questionnaire of this study used an enclosed questionnaire with five alternative answers prepared by Likert's scale. The rating scale consists of; (1) strongly disagree, (2) do not agree, (3) neutral, (4) agree, (5) strongly agree.

Before testing the PSM's difference, researchers will calculate PSM mean of permanent and contract employees by using the index number. To determine a judgment on the results of the calculation of index number, determinants tables was used with a range of 0.80 interval. Interval $1.00-1.80$ (very low), 1.81-2.60 (low), 2.613.40 (medium), 3.41-4.20 (high), 4.21-5.00 (very high). Data were analyzed using T-test (independent sample T-test) with the help of statistical package for the social sciences (SPSS) 20 to test the hypotheses of this study.

\section{Discussion the Differences of PSM}

Table 4.1 illustrates average PSM differences of permanent and contract employees by using the index number. From table 4.1, it was known that PSM of contract employees is higher than permanent employees. The Calculation of PSM average for each category of employees showed that there were different grades of PSM between permanent and contract employees. The results of calculation of average values for each category of PSM showed that PSM of 
permanent employees (3.96) was lower than contract employees (4.03). In other words, PSM of contract employees was higher 0.07 than PSM of permanent employees.

From Table 4.2, it shows that the results $t_{\text {count }}$ of permanent and contract employees at the street-level bureaucracy is equal to 0.991 . Based on the hypothesis formulated test criteria, if $t_{\text {count }>} t_{\text {table }}$ then the hypothesis is rejected and if $t_{\text {count }}<t_{\text {table }}$ then the hypothesis is accepted. Value of $t_{\text {count }}=0.991$ and compared with $\mathrm{t}_{\text {table }} 1.971$ with $\mathrm{df}=201$ and significance level of $5 \%(p \leq 0.05)$, so the hypothesis was accepted. It can be concluded that there is no PSM difference between permanent and contract employees at the street-level bureaucracy in Tanjungpinang administration.

Judging from the average value for each dimension, both permanent and contract employees, it has a value of PSM above 3.50. This data indicates that PSM of employees at the street-level bureaucracy was higher than PSM of employees. The findings of present study followed the

study of DeHart-Davis et al. (2006), Taylor (2007), Wright and Pandey (2008), Komalasari et al. (2009), dan Syamsir (2014). However, judging from the average value of each category, PSM of permanent employees was lower than contract employees. The findings differ from the study of Brewer (2003), Frank and Lewis (2004), Houston (2006), Steijn (2008), Yanti (2012) which showed that PSM of public sector employees was higher than PSM of private sector employees. These studies also suggested that there was significant differences between PSM of public sector employees which were higher than PSM of private sector employees. The results of this study also refuted the findings of Bangcheng (2009), Wright and Christensen (2010), Bright (2011) which revealed that there was no relationship between PSM and someone's choice for a career as a public sector employee.

This present study shows that in the context of developing countries, motivation and performance of employees are influenced by socio-cultural factors (Grindle, 1997). This research supports the study of Frank and Lewis (2004), Benz (2005), Buelens and Van den Broeck (2007), Serneels et al (2007), Lee and Wilkins (2011), Syamsir (2014), Van de Walle et al (2015) discussing the importance to consider the context and socio-cultural environment in reviewing PSM at international level. Ritz and Brewer (2013) also mentioned that PSM was strongly influenced by social and cultural conditions. The findings of this study indicated that there were non-PSM factors affecting the motivation of civil services. From a theoretical perspective, this study contributed to the study of PSM. In the context of PSM in Indonesia, there were some scholars reviewing PSM, for instance Komalasari et al. (2009), Yanti (2012), Syamsir (2014), but they did not focus on PSM at street-local bureaucracy in the local government.

Table 1

Mean of PSM Permanent and Contract Employees ofTanjungpinang

\begin{tabular}{|l|c|c|}
\hline \multicolumn{1}{|c|}{ Dimensions } & $\begin{array}{c}\text { Permanent } \\
(N=129)\end{array}$ & $\begin{array}{c}\text { Contract } \\
(N=74)\end{array}$ \\
\hline Attraction to policy making & 4.01 & 3.50 \\
Commitment to the public interest & 3.52 & 4.38 \\
Compassion & 4.43 & 4.36 \\
Self-sacrifice & 3.87 & 3.90 \\
Mean & 3.96 & 4.03 \\
\hline
\end{tabular}

Table 2

Model of Hypothesis

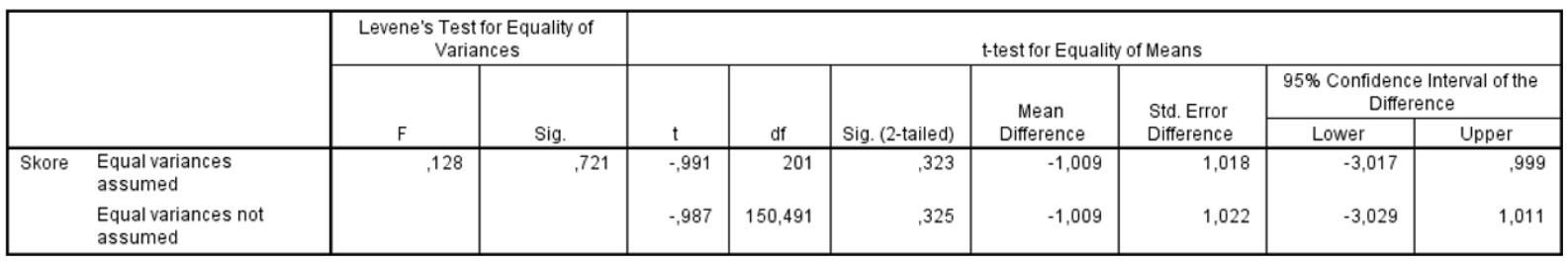

Note: $p \leq 0.05$ 
Table 3

Average of PSM Differences between Public and Private Sector Employees in Developed and Developing Nations

\begin{tabular}{|c|c|c|c|}
\hline \multirow{2}{*}{ Researcher(s) } & \multirow{2}{*}{ Responden } & \multicolumn{2}{|c|}{ Mean of PSM } \\
\hline & & Public & Private \\
\hline DeHart-Davis et al (2006) & $\begin{array}{l}274 \text { managers and staffs from } 50 \text { states } \\
\text { and Washington D.C }\end{array}$ & 3.58 & - \\
\hline Taylor (2007) & $\begin{array}{l}203 \text { public sector employees in } \\
\text { Australia }\end{array}$ & 3.50 & - \\
\hline Wright and Pandey (2008) & $\begin{array}{l}518 \text { from } 7 \text { public sector organizations } \\
\text { (local dan state), employees and } \\
\text { managers from } 50 \text { states and } \\
\text { Washington D.C (city manager, } \\
\text { education, health, and human service) }\end{array}$ & 3.62 & - \\
\hline Komalasari et al (2009) & $\begin{array}{l}145 \text { (civil service on } 4 \text { regencies } \\
\text { government and civil service in the } \\
\text { Administration of East Java Province), } \\
\text { Indonesia }\end{array}$ & 3.95 & - \\
\hline Yanti (2012) & $\begin{array}{l}451 \text { (Permanent and contract } \\
\text { employees) in health sector and } \\
357 \text { employees in the City of Jambi } \\
\text { Administration, Indonesia }\end{array}$ & $24.39 *$ & $23.65 * *$ \\
\hline Syamsir (2014) & $\begin{array}{l}398 \text { (Federal civil services, employees } \\
\text { in the Government of Sumatera Barat } \\
\text { Province, employees in the Government } \\
\text { of Padang City, Indonesia }\end{array}$ & 3.44 & - \\
\hline
\end{tabular}

Note: * Scale used 1-7; ** Not examining PSM of private sector or contract employee

This study indicated that PSM of permanent employees did not have significant differences with PSM of contract employees. It means, both permanent and contract employees have approximately the same motivation. This happened because the motivation of the person to become an employee (whether permanent or contract employee) is due to extrinsic rather than intrinsic factors. The findings were consistent with Nawab's et al. (2011) research revealing no difference in motivation between government and private sector employees in Pakistan. Public sector employees were less concerned with intrinsic value because it was more driven by extrinsic factors. Meanwhile, private sector employees were more committed to their job than government employees. This result is also consistent with the study of Andersen et al. (2011) in Denmark. Andersen et al. (2011) found that there was no significant differences between PSM of public and private phsyoteraphists. Viewed from every dimension of PSM, Andersen et al (2011) showed that the average of commitment to the public interest dimension of public phsyoteraphists was 1.77 points higher than private phsyoteraphists. Then, private phsyoteraphists have dimension of customer needs orientation was 1.28 points higher than public phsyoteraphists. Compassion of public phsyoteraphists was higher than private phsyoteraphists, but the level of attraction to policy making of public phsyoteraphists were lower than private phsyoteraphists. This study also confirms the findings of Yung (2014) who revealed that PSM of public sector employees in Hong Kong was low because employees were motivated by personal interests, for example certainty and safety, as well as remuneration packages offered.

\section{Conclusions}

This study concludes that PSM of permanent employees was lower than contract employees. This study also found that there was no difference between PSM of permanent and contract employees. This research confirms the study employed by Nawab et al. (2011), Andersen et al. (2011), and Yung (2014). However, this study's findings differ from the study of Rainey (1982), Wittmer (1991), Crewson (1997), Houston (2000), Choi (2001), Frank and Lewis (2004), Steijn (2008), and Yanti (2012). The present study also showed that the concept of PSM is not entirely viable for developing countries, such as Indonesia. This is due to 
the motivation of individuals to become civil servants affected by various extrinsic factors, for instance salaries and benefits, old age security, and prestige.

This research contributed to the study of public administration in two aspects. First, in the context of street-level bureaucracy, the scholars need to re-examine every dimension contained in the PSM. Secondly, the scholars should consider a wide range of socio-political, cultural and economic dimensions when testing the PSM in the context of developing countries. Limitations of this study lies in the area of research limited at one city, using similar samples, and employees working on sub-districts in local government. In addition, contract employees tested in this study, in the context of Indonesia, cannot be fully equated with private employees in developed countries. Administratively and managerially, in Indonesia after Law No. 5 of 2015 on State Civil Apparatus (Aparatur Sipil Negara) was formulate $d$, both permanent and contract employees have already had many similarities in some aspects, such as workload, salaries, and benefits, as well as other social insurance. Therefore, this study may be opening the horizon to discover a variety of extrinsic factors affecting PSM civil servants, either by using quantitative and qualitative methods. In addition, this study needs to be tested again in larger sample and diverse to obtain valid results for the development of the study of PSM in Indonesia.

In practical terms, the findings of this research can be seen as recommendation for local government to improve the system of recruitment and development of public sector employees. Permanent employees should have higher PSM than contract employees because permanent employees gain larger and clearer allowances and compensation than contract e mployees. However, the present research found the otherwise where PSM of contract employees greater than permanent employees of street-level bureaucracy. Therefore, the government should work up the patterns of civil service recruitment by integrating models or systems accommodating the test of competence and PSM indicators. The aim is to attract individuals who have a greater intrinsic motivation than extrinsic rewards. In addition, developing career of civil services need to ensure the dimensions of PSM, such as attraction to policy making, commitment, compassion, self-sacrifice as a pre-requisite for promotion, degree, and job title. PSM assessment should be enforced for every permanent employee promoted to a higher position. Promoting public employees into higher level should consider the results of PSM examination.

\section{References}

Adams, J. Stacy. (1965). Inequity in Social Exchange in L. Berkowitz (Ed) Advances in Experimental Social Psychology (Vol. 2, pp. 267-299). New York: Academic Press.

Ahmad, Badu and Baharuddin. (2011). Analyzing Competence and Performance of the Recruitment of Contract Employee Become Permanent Employee in the Government of Makassar City. Fundamental Research Report for Institute of Research and Community Service, the University of Hasanuddin.

Alonso, Pablo and Gregory B. Lewis. (2001). Public Service Motivation and Job Performance: Evidence from the Federal Sector. American Review of Public Administration, Vol. 31 No. 4 (December).

Andersen, Lotte Bøgh et al. (2011). Does Ownership Matter? Public Service Motivation among Physiotherapists in the Private and Public Sectors in Denmark. Review of Public Personnel Administration, Vol. 31 No. 1 (March).

Central Bureau of Statistics. (2015). Statistik Indonesia (Statistical Yearbook of Indonesia) 2015. Jakarta: Badan Pusat Statistik.

Baharuddin. (2015). Akuntabilitas Pelayanan Publik: Studi Kasus Pelayanan Perizinan Mendirikan Bangunan di Kota Makassar [Public Service Accountability: Case Study on Building Permit in the City of Makassar]. Mimbar: Jurnal Sosial dan Pembangunan Vo. 31 No. 2 (December).

Bandura, Albert. (1977). Self-efficacy: Toward a Unifying Theory of Behavioral Change. Psychological Review, Vol. 84 No. 2 (March).

Bangcheng, Liu. (2009). Evidence of Public Service Motivation of Social Workers in China. International Review of Administrative Sciences, Vol. 75 No. 2 (June).

Behn, Robert D. (1995). The Big Questions of Public Management. Public Administration Review, Vol. 55 No. 4 (July-August).

Benz, Matthias. (2005). Not for the Profit, but for the Sastisfaction?-Evidence on Worker Well-Being in Non-Profit Firms. Kyklos, Vol. 58 No. 2 (May). 
Bertelli, Anthony M. (2006). Motivation Crowding and the Federal Civil Servant: Evidence from the US Internal Revenue Service. International Public Management Journal, Vol. 9 No. 1 (Jan-March).

Brewer, Gene A. (2003). Building Social Capital: Civic Attitudes and Behavior of Public Servants. Journal of Public Administration Research and Theory, Vol. 13 No. 1 (January).

Brewer, Gene A. and Sally Colemen Selden. (1998). Whistle Blowers in the Federal Civil Service: New Evidence of the Public Service Ethic. Journal of Public Administration Research and Theory, Vol. 8 No. 3 (July).

Brewer, Gene A. and Sally Colemen Selden. (2000). Why Elephants Gallop: Assessing and Predicting Organizational Performance in Federal Agencies. Journal of Public Administration Researh and Theory, Vol. 10 No. 4 (October).

Brewer, Gene. A. et al. (2000). Individual Conceptions of Public Service Motivation. Public Administration Review, Vol. 60 No. 3 (May/June).

Bright, Leonard. (2011). Does Public Service Motivation Affect the Occupation Choices of Public Employees?. Public Personnel Management, Vol. 40 No. 1 (Spring).

Buelens, Marc and Herman Van den Broeck. (2007). An Analysis of Differences in Work Motivation between Public and Private Sector Organizations. Public Administration Review, Vol. 67 No. 1 (February).

Camilleri, Emanuel. (2006). Towards Developing an Organisational Commitment-Public Service Motivation Model for the Maltese Public Service Employees. Public Policy and Administration, Vol. 21 No. 1 (Spring).

Camilleri, Emanuel. (2007). Antecedents Affecting Public Service Motivation. Personnel Review, Vol. 36 No. 3 (May).

Castaing, Sébastien. (2006). The Effects of Psychological Contract Fulfillment and Public Service Motivation on Organizational Commitment in the French Civil Service. Public Policy and Administration, Vol 21 No. 1 (Spring).

Choi, Do Lim. (2004). Public Service Motivation and Ethical Conduct. International Review of Public Administration, Vol. 8 No. 2 (July).

Choi, Young Jun. (2001). A Study of Public Service Motivation: The Korean Experience. Dissertation in the College of Graduate Studies University of Idaho.
Christensen, Robert K. and Bradley E. Wright. (2011). The Effects of Public Service Motivation on Job Choice Decisions: Disentangling the Contributions of Person-Organization Fit and Person-Job Fit. Journal of Public Administration Research and Theory, Vol. 21 No. 4 (October).

Crewson, Philip E. (1995). A Comparative Analysis of Public and Private Sector Entrant Quality. American Journal of Political Science, Vol. 39 No. 3 (August).

Crewson, Philip E. (1997). Public-Service Motivation: Building Empirical Evidence of Incidence and Effect. Journal of Public Administration Research and Theory, Vol. 7 No. 4 (October).

Deci, Edward L. (1976). Intrinsic Motivation, Second Printing. New York: Plenum Press.

DeHart-Davis, Leisha et al. (2006). Gender Dimensions of Public Service Motivation. Public Administration Review, Vol. 66 No. 6 (December).

Frank, Sue A. and Gregory B. Lewis. (2004). Government Employees: Working Hard or Hardly Working?. American Review of Public Administration, Vol. 34 No. 1 (March).

Frederickson, H. George and David K. Hart. (1985). The Public Service and the Patriotism of Benevolence. Public Administration Review, Vol. 45 No. 5 (September-October).

Frey, Bruno S. and Margit Osterloh (Eds). (2002). Successful Management by Motivation: Balancing Intrinsic and Extrinsic Incentives. Berlin: SpringerVerlag.

Gabris, Gerald T. and Gloria Simo. (1995). Public Service Motivation as an Independent Variable Affecting Career Decisions. Public Personnel Management, Vol. 24 No. 1 (March).

Grindle, Merilee S. (1997). Divergent Cultures? When Public Organizations Perform Well in Developing Countries. World Development, Vol. 25 No. 4 (January).

Hardiyansyah. (2012). Analisis Kualitas Pelayanan Mendirikan Bangunan pada Dinas Tata Kota di Kota Palembang [Analyzing Service Quality of Building Permit in the Board of City Planning of Palembang]. Mimbar: Jurnal Sosial dan Pembangunan Vo. 28 No. 2 (December).

Houston, D. J. (2000). Public Service Motivation: A Multivariate Test. Journal of Public Administration Research and Theory, Vol. 10 No. 4 (October). 
Houston, David J. (2006). "Walking the Walk" of Public Service Motivation: Public Employees and Charitable Gifts of Time, Blood, and Money. Journal of Public Administration Research and Theory, Vol. 16 No. 1 (January).

Heller, Peter and Alan A. Tait. (1983). Government Employment and Pay: Some International Comparisons. Finance and Development (September).

Kachornkittiya, Nattee et al. (2012). Factors Affecting Public Service Motivation: Empirical Study of Municipal Employees in the Three Southern Border Provinces of Thailand. International Journal of Business and Social Science, Vol. 3 No. 18 (September).

Kanfer, Ruth et al (Eds). (2008). Work Motivation: Past, Present, and Future. New York: Routledge.

Kim, Sangmook. (2005). Individual LevelFactors and Organizational Performance in Government Organizations. Journal of Public Administration Researh and Theory, Vol. 15 No. 2 (April).

Kim, Sangmook. (2006). Public Service Motivation and Organizational Citizenship Behavior in Korea. International Journal of Manpower, Vol. 27 No. 8.

Kim, Sangmook. (2009). Testing the Structure of Public Service Motivation in Korea: A Research Note. Journal of Public Administration Research and Theory, Vol. 19 No. 4 (October).

Kim, Sangmook and Wouter Vandenabeele. (2010). A Strategy for Building Public Service Motivation Research Internationally. Public Administration Review, Vol. 70 No. 5 (September/ October).

Kim, Seung Hyun and Sangmook Kim. (2016). National Culture and Social Desirability Bias in Measuring Public Service Motivation. Administration and Society, Vol. 48 No. 4 (May).

King, Dwight Y. (1988). Civil Service Policies in Indonesia: An Obstacle to Decentralization?. Public Administration and Development, Vol. 8 No. 3 (July/ September).

Kjeldsen, Anne Mette. (2012). Dynamics of Public Service Motivation. Ph.D Dissertation at the Department of Political Science and Government Business and Social Sciences Aarhus University.

Komalasari, Puput Tri et al. (2009). Pengaruh Public Service Motivation dan Organizational Citizenship Behavior terhadap Kinerja Organisasi
Pemerintahan[The Effects of Public Service Motivation and Organizational Citizenship Behavior on the Performance of Governmental Organization]. Jurnal Manajemen Teori dan Terapan, Vol. 2 No. 2 (Agustus).

Latham, Gary P. (2007). Work Motivation: History, Theory, Research, and Practice. Thousand Oaks, CA: Sage.

Latham, Gary P. and Edwin A. Locke. (1979). Goal Setting-A Motivational Technique That Works. Organizational Dynamics, Vol. 8 No. 2 (Autumn).

Leisink, Peter and Bram Steijn. (2009). Public Service Motivation and Job Performance of Public Sector Employees in the Netherlands. International Review of Administrative Sciences, Vol. 75 No. 1 (March)

Lee, Young-joo and Vicky M. Wilkins. (2011). More Similarities or More Differences? Comparing Public and Nonprofit Managers' Job Motivations. Public Administration Review, Vol. 71 No. 1 (January/February).

Liu, Bangcheng. (2009). Evidence of Public Service Motivation of Social Workers in China. International Review of Administrative Sciences, Vol. 75 No. 2 (June).

Liu, Bangcheng, et al. (2008). Public Service Motivation and Job Satisfaction in China: An Investigation of Generalisability and Instrumentality. International Journal of Manpower, Vol. 29 No. 8.

Liu, Bangcheng, et al. (2014). Compassion as the Affective Dimension of Public Service Motivation in a Chinese Context. Social Behavior and Personality, Vol. 42 No. 2.

Maslow, Abraham. (1954). Motivation and Personality. New York: Harper and Row.

Morrison, J. C. (2012). The Impact of Public Service Motivation on Turnover Intentions of Federal Employees. Dissertation in the Graduate School of the University of Alabama.

Moynihan, Donald P. and Sanjay K. Pandey. (2007). The Role of Organizations in Fostering Public Service Motivation. Public Administration Review, Vol. 67 No. 1 (January/February).

Naff, Katherine C. and John Crum. (1999). Working for America: Does Public Service Motivation Make a Difference?. Review of Public Personnel Administration, Vol. 19 No. 1 (October).

Nawab, Samina et al. (2011). An Analysis of Differences in Work Motivation between Public and Private Sector Organizations. 
Interdisciplinary Journal of Contemporary Research in Business, Vol. 2 No. 11 (March).

Nugroho, M. Kris. (2004). Analyzing the Factors Relationship with Public Nurse Performance in Kudus Regencey Puskemas. Thesis at the Graduate School of Public Health, Diponegoro University.

Octarina, Arischa. (2013). Pengaruh Etos Kerja dan Disiplin Kerja terhadap Kinerja Pegawai pada Dinas Kebudayaan, Pariwisata, Pemuda dan Olahraga Kabupaten Sarolangun [The Effects of Work Ethos and Work Discipline on Employe Performance at the Board of Culture, Tourism, Youth and Sport of Sarolangun]. Jurnal Karya Mahasiswa, Vol. 1 No. 1.

Perry, James L. (1996). Measuring Public Service Motivation: An Assessment of Construct Reliability and Validity. Journal of Public Administration Research and Theory, Vol. 6 No. 1 (January).

Perry, James L. (1997). Antecedents of Public Service Motivation. Journal of Public Administration Research and Theory, Vol. 7 No. 2 (April).

Perry, James L. (2000). Bringing Society In: Toward a Theory of PublicService Motivation. Journal of Public Administration Research and Theory, Vol. 10 No. 2 (April).

Perry, James L. (2014). The Motivational Bases of Public Service: Foundations for a Third Wave of Research. Asia Pacific Journal of Public Administration, Vol. 36 No. 1 (January).

Perry, James L. and Lois RecascinoWise. (1990). The Motivational Bases of Public Service. Public Administration Review, Vol. 50 No. 3 (May/June).

Perry, James L. and Annie Hondeghem. (Eds). (2008a). Motivation in Public Management: The Call of Public Service. Oxford: Oxford University Press.

Perry, J. L. and Hondeghem, A. (2008b). Building Theory and Empirical Evidence about Public Service Motivation. International Public Management Journal, Vol. 11 No. 1 (January).

Perry, James L. et al. (2008). What Drives Morally Committed Citizens?: A Study of the Antecedents of Public Service Motivation. Public Administration Review, Vol. 68 No. 3 (May/June).

Perry, James L. et al. (2010). Revisiting the Motivational Bases of Public Service: Twenty Years of Research and an Agenda for the Future. Public Administration
Review, Vol. 70 No. 5 (September/ October).

Prasojo, Eko. (2007). An Analysis of the Government Systems in Indonesia. Draft of the Final Report for Administrative Sciences Department University of Indonesia and Korea-Australasia Research Centre the University of New South Wales.

Rainey, Hal G. (1979). Perceptions of Incentives in Business and Government: Implications for Civil Service Reform. Public Administration Review, Vol. 39 No. 5 (September/October).

Rainey, Hal G. (1982). Reward Preferences among Public and Private Managers: In Search of the Service Ethic. American Review of Public Administration, Vol. 16 No. 4 (Winter).

Rainey, Hal G. (1983). Public Agencies and Private Firms: Incentive Structures, Goals, and Individual Roles. Administration and Society, 15(2): 207-242.

Rainey, Hal G. (2003). Understanding and Managing Public Organizations, Third Edition. San Fransisco: Jossey-Bass.

Rainey, Hal G. and Paula Steinbauer. (1999). Galloping Elephants: Developing Elements of a Theory of Effective Government Organizations. Journal of Public Administration Research and Theory, Vol. 9 No. 1 (January).

Ritz, Adrian. (2009). Public Service Motivation and Organizational Performance in Swiss Federal Government. International Review of Administrative Sciences, Vol 75 No. 1 (March).

Ritz, Adrian and Gene A. Brewer. (2013). Does Societal Culture Affect Public Service Motivation? Evidence of Subnational Differences in Switzerland. International Public Management Journal, Vol. 16 No. 2 (April).

Sansone, Carol and Judith M. Harackiewicz (Eds). (2000). Intrinsic and Extrinsic Motivation: The Search for Optimal Motivation and Performance. San Diego, CA: Academic Press.

Serneels, Pieter et. al. (2007). For Public Service or Money: Understanding Geographical Imbalances in the Health Workforce. Health Policy and Planning, Vol. 22 No. 3 (May).

Shim, Dong Chul et al. (2015). StreetLevel Bureaucrats' Turnover Intention: Does Public Service Motivation Matter?. International Review of Administrative Sciences, Vol. 81 No. 3 (September).

Schiavo-Campo, Salvatore. (1998). 
Government Employment and Pay: The Global and Regional Evidence. Public Administration and Development, Vol. 18 No. 5 (December).

Steijn, Bram. (2008). Person-Environment Fit and Public Service Motivation. International Public Management Journal, Vol. 11 No. 1 (January).

Syamsir. (2014). Public Service Motivation and Socio Demographic Antecedents among Civil Service in Indonesia. Jurnal Ilmu Administrasi dan Organisasi, Bisnis dan Birokrasi, Vol. 21 No. 1 (January).

Taylor, Jeannette. (2007). The Impact of Public Service Motives on Work Outcomes in Australia: A Comparative Multi-Dimensional Analysis. Public Administration, Vol. 85 No. 4 (December).

Taylor, Jeannette. (2008). Organizational Influences, Public Service Motivation and Work Outcomes: An Australian Study. International Public Management Journal, Vol. 11 No. 1 (January).

Tejada, Jeffry J. and Joyce Raymond B. Punzalan. (2012). On the Misuse of Slovin's Formula. The Philippine Statistician, Vol. 61 No. 1 (January).

Thomas, Kenneth W. (2009). Intrinsic Motivation at Work: What Really Drives Employee Engagement. San Fransisco, CA: Berrett-Koehler.

Tjiptoherijanto, Prijono. (2007). Civil Service Reform in Indonesia. International Public Management Review, Vol. 8 No. 2 (July).

Vandenabeele, Wouter. (2007). Toward a Public Administration Theory of Public Service Motivation. Public Management Review, Vol. 9 No. 4 (December).

Vandenabeele, Wouter. (2011). Who Wants to Deliver Public Service?: Do Institutional Antecedents of Public Service Motivation Provide an Answer?. Review of Public Personnel Administration, Vol. 31 No. 1 (December).

Vandenabeele, Wouter et al. (2004). The Civil Service as an Employer of Choice in Belgium. Review of Public Personnel Administration, Vol. 24 No. 4 (December). Vandenabeele, Wouter et al. (2006). Public Service Motivation in an International Comparative Perspective: The UK and Germany. Public Policy and Administration,
Vol. 21 No. 1 (Spring).

Vandenabeele, Wouter et. al. (2010). The Relationship between Public Service Motivation and Civil Servant's Job Satisfaction in Various European Countries. Paper presented at 'Reforming the Public Sector-How to Make the Difference', 2 December, Rome, Italy.

Van de Walle, Steven et al. (2015). Extrinsic Motivation, PSM and Labour Market Characteristics: A Multilevel Model of Public Sector Employment Preference in 26 Countries. International Review of Administrative Sciences, Vol. 81 No. 4 (March).

Wittmer, Dennis. (1991). Serving the People or Serving for Pay: Reward Preferences among Government, Hybrid Sector, and Business Managers. Public Productivity and Management Review, Vol. 14 No. 4 (Summer).

World Bank. (2003). Decentralizing Indonesia: A Regional Public Expenditure Review. Overview Report by East Asia Poverty Reduction and Economic Management Unit.

Wright, Bradley E. and Robert K. Christensen. (2010). Public Service Motivation: A Test of the Job Attraction-Selection-Attrition Model. International Public Management Journal, Vol. 13 No. 2 (October).

Wright, Bradley E. and Sanjay K. Pandey. (2008). Public Service Motivation and the Assumption of Person-Organization Fit: Testing the Mediating Effect of Value Congruence. Administration and Society, Vol. 40 No. 5 (September).

Yanti, M. (2012). Public Service Motivation and Job Satisfaction in Jambi, Indonesia. Dissertation in the Capella University.

Yudiatmaja, Wayu Eko, Alfiandri and Rahmat Hidayat. (2017). Far from Fire: The Service Delivery Quality Gap Plaguing Indonesian Ports. JKAP (Jurnal Kebijakan dan Administrasi Publik), Vol. 21 No. 1 (May).

Yung, Betty. (2014). Differential Public Service Motivation among Hong Kong Public Officials: A Qualitative Study. Public Personnel Management, Vol. 43 No. 4 (December). 